\title{
Teaching Reflective Writing as Part of EFL Teacher Training
}

\author{
N. M. Odegova
}

H. S. Skovoroda Kharkiv National Pedagogical University, Kharkiv, Ukraine

Paper received 01.05.18; Accepted for publication 05.05.18.

\section{http://doi.org/10.31174/SEND-PP2018-165VI69-06}

\begin{abstract}
The article deals with the issue of developing reflective writing skills in the course of training future EFL teachers and contains an account of a case study conducted at H. S. Skovoroda Kharkiv National Pedagogical University in the 2016/17 academic year. The subjects of the research (24 second-year students of the Foreign Philology Faculty) were provided with training which was meant to develop both the skills of reflection and the skills of writing an essay. By the end of the training the participants' average proficiency quotient reached the minimum satisfactory level on the Bespalko scale $(0,7)$, in view of which the results of the training can be considered positive.
\end{abstract}

Keywords: reflective writing skills, future EFL teachers, case study, training, proficiency quotient.

Introduction. Among the skills that determine a teacher's professional development a prominent position is occupied by reflection as it provides opportunities for grasping the meaning of ideas and experiences. Engaging in reflective writing is particularly beneficial due to the specific nature of writing, which typically requires one to organize one's thoughts before putting them on paper. For this reason, teaching reflective writing to future EFL teachers takes on special importance, which necessitates developing an appropriate methodology and designing corresponding activities.

Brief review of publications on the topic. For over two decades now the methodology of teaching writing has been extensively researched by Ukrainian scientists who produced a considerable number of works covering a wide range of issues, such as the organization of the teaching-learning process (Bebykh, 2009; Krivchykova, 2005), the use of teaching aids (Hlazunova, 1997; Kamenieva, 2010), teaching writing for specific purposes (Synekop, 2015; Ustymenko, 2002) etc. There have been explored both practical (Lytvyn, 2002) and academic (Schur, 2003; Vasylieva, 2005) genres. Among the latter there feature different types of essays, yet "reflective essay" so far has escaped the attention of Ukrainian methodologists. Taking into consideration this lack of research on the one hand and the obvious gains from practicing reflection on the other hand we decided to carry out a case study as an attempt to explore ways of developing reflective writing skills when training future EFL teachers. Consequently, the aim of this article is to provide an account of the above-mentioned study and to discuss the results.

Materials and methods. The research was conducted as part of the project "New Generation School Teacher" jointly initiated by the British Council Ukraine and the Ministry of Education and Science Ukraine with the purpose of introducing "change to the initial teacher education system in Ukraine" [5]. Currently, there takes place the piloting of a new Curriculum on English language Methodology, designed by the project team. One of the distinguishing features of the new Curriculum is a strong orientation towards reflection - at the end of each module students are expected to write reflective accounts of both their own learning experience and the contents of the course. The quality of the students' reflective writing produced at the end of the first module was predictably low as presently reflection can hardly be called a wide- spread practice at Ukrainian schools and universities (according to the surveys conducted among both teachers and students). So it was decided to provide the participants of the project (24 second-year students of the Foreign Philology Faculty at H. S. Skovoroda Kharkiv National Pedagogical University) with training in reflective writing, which lasted throughout the second term of the 2016/17 academic year and became the object of our case study.

To organize the training, the following tasks needed to be carried out: exploring the basic nature of reflective writing; identifying the skills that enable university students to produce reflective essays; designing activities aimed at developing the above-mentioned skills.

The word "reflection" comes from the Latin "reflexio" (which means "turning back") and denotes a process that entails introspection and critical thinking [1, p. 247-248]. Reflection allows one to look back on an experience, see it more clearly as part of the bigger picture and respond to it by analyzing the meaning of that experience - how it affected one at the time and what can be learnt from it. Reflection also takes place when a person tries to relate new ideas to what they already know or bring together theory and practice, which may result in challenging their assumptions [3, p. 2-3]. All in all, it is obvious that reflective writing presents a considerable challenge for students as the writing process is preceded or goes together with a complex thought process. To make it possible for the participants of the project to cope with this challenge, we identified the essential skills of reflective writing, in our case those of composing a reflective essay. The skills in question are comprised of two groups: the skills of reflection and the basic skills of writing an essay.

Accordingly, the first group includes such skills as: examining and evaluating an experience (one's behaviour, feelings, thoughts etc); analysing an experience (its causes and consequences, the similarities/differences with similar events etc); speculating on what could have been done differently and what can be learnt from an experience; making connections between an experience and the corresponding theory. The second group covers the following skills: expressing one's thoughts clearly and precisely; composing the basic structural elements of a written text (the introduction, the body paragraphs, and the conclusion); achieving coherence and cohesion of the text; editing the written text. 
Dividing the skills of reflective writing into two groups does not mean, however, that their development can be arranged as a linear process - they are bound to overlap as reflection by no means stops when one sets pen to paper. Still, in order to know what exactly to write, students need to learn the basic skills of reflection as it is likely to be something they have not consciously engaged in before.

The way we singled out the above-given skills of reflection may seem somewhat artificial as in real life it might be difficult to draw a line between the specified thought processes. Yet in the classroom, breaking up reflection, which students are certain to perceive as a complex and relatively novel process, into manageable tasks seems more learner-friendly and thus more practical.

To develop the specified above skills, there was designed a set of activities to be done by the subjects of our case study. Below one can see a selection of sample activities:

1) Purpose: to develop the skills of speculating on what could have been done differently and what can be learnt from an experience.

Instructions: Look back on the two final years of your school life. Consider the questions below. You have 5 minutes to answer them. Write what comes to your mind without stopping. Focus on the content not the form.

- What might I have done differently?

- What did I learn from this experience?

2) Purpose: to practice the skills of expressing one's thoughts clearly and precisely.

Instructions: You have been asked to share your reflections (see the previous activity) with your fellow students. Read through your answers and rewrite them bearing in mind that the readers may not be familiar with your personal details so your writing should be as clear and comprehensible as possible.

3) Purpose: to develop the skills of making connections between an experience and the corresponding theory.

Instructions: In the course of methodology you have got acquainted with Bloom's Taxonomy of Learning Levels. Think of your own learning experience and consider it in the light of this taxonomy. Prepare to share your reflections with your group mates by answering the questions below. You have 15 minutes to put your ideas on paper.

- Did/do you practice all levels of thinking at school/university?

- Which ones predominate $(d)$ ?

- How did/does it affect your cognitive development?

4) Purpose: to develop the skills of making connections between an experience and the corresponding theory.

Instructions: You have been invited to respond to a survey conducted by the British Council with the aim of determining the general level of learner autonomy among Ukrainian students. Part of this survey is the participants' self-evaluation of how autonomous they are as learners. Write your reflective statement (approx. 150 words). Refer to the theoretical issues you discussed within the unit on learner autonomy.

Due to its nature, reflection is not necessarily a properly organized process. It could result in rather chaotic and rambling writing. However, if it is meant for a certain reader other than the author and if it is to be presented in the form of an essay, a reflective piece of writing should be well-structured, that is, comprised of the basic building blocks of a written text: the introduction, the main body, the conclusion. It is our belief that each of these structural elements requires specially intended practice (see the activities below).

5) Purpose: to acquire a working knowledge of writing a thesis statement.

Instructions: Work in pairs. Study the following statements about a good thesis and decide which are true and which are false.

\section{Guidelines for Writing a Good Thesis}

1. A good thesis is an announcement of the subject mat-

1. ter or a description of your intentions.

2. A good thesis states a fact.

3. A good thesis states the writer's clearly defined opinion on some subject.

A good thesis contains such expressions as "I believe

4. ...", "in my opinion ...", "in this essay I will argue that ..." etc.

5. A good thesis asserts one main idea.

6. A good thesis states the obvious.

7. A good thesis is limited to fit the assignment.

8. A good thesis is clearly stated in specific terms.

6) Purpose: to develop the skills of writing a thesis statement.

Instructions: One of your group mates has started a blog aimed at sharing his/her life experience with other students. The readers are welcome to contribute to the blog by submitting a reflective essay on their personal growth. Consider the topics given below. You have 10 minutes to choose one and compose a thesis statement for your future essay.

1)Learning from Mistakes 2) My Extraordinary

Achievement 3) My Experience of Learning English

7) Purpose: to practice the skills of composing an introductory paragraph.

Instructions: Use your thesis statement from the previous activity to write an introduction for your reflective essay. To start the paragraph, you can make use of one of the following introductory devices: providing relevant background information, giving pertinent statistics, asking a provocative question, using an appropriate quotation, making an intriguing or shocking statement etc [6, p. 106; 7, p. 82].

8) Purpose: to practice the skills of composing body paragraphs.

Instructions: Continue writing your reflective essay (Activities 6, 7) by adding the main body (2-3 paragraphs). Make sure that each paragraph contains a topic sentence and is characterized by coherence and cohesion.

9) Purpose: to gain a working knowledge of writing a concluding paragraph.

Instructions: Below you can see a number of 'gapped' tips for writing a conclusion. In pairs, complete them by adding Do or Don't.

... announce what you have done, e.g. "In this essay I have shared my reflections on ...".

... restate the thesis but not word for word.

... introduce new points.

... change your stance (i.e. opinion).

... make sure that the conclusion reinforces and reaffirms the ideas communicated in the essay. 
10) Purpose: to practice the skills of composing a concluding paragraph.

Instructions: Look through your unfinished essay for your group mate's blog (Activities 6, 7,8) and wrap it up with an appropriate conclusion.

11) Purpose: to practice editing skills.

Instructions: Read through your essay carefully, considering the questions in the checklist below. Make the necessary changes.

- Does the opening sentence stir up the reader's interest?

- Does the thesis statement indicate the reflective nature of the essay?

- Does each paragraph contribute to the overall idea of the essay by presenting and developing one main point in the discussion of the thesis?

- Are the paragraphs long enough to accomplish their purpose and short enough to hold the reader's attention (3-6 sentences)?

- Does the essay show enough evidence of reflection?

- Does the conclusion logically follow from the main body and does it correlate with the introduction?

- Is there any irrelevant information in the text?

- Are the ideas expressed clearly enough?

- Is the text grammatically and lexically accurate?

- Does the style of the text correspond to its type and the target reader?

It is worth pointing out that despite there having been identified two groups of skills to be developed (those of reflection and those of writing an essay), most of the activities described above address both: reflective skills are practised through writing and the writing activities are oriented towards producing a reflective essay. This was exactly our intention as the initial focus on either writing or reflective skills was just a step to make acquiring them more manageable for students. In real life, though, it is difficult to draw a line between the two processes.

Results and discussion. At the end of the spring term 2017, the subjects of our case study were asked to write a reflective essay. The writing the students produced was compared with that done at the end of the autumn term 2016 (before they received the training). Both tasks can be seen below. The assessment criteria [4, p. 3, 12] are specified in Table 1.

Term I - Write a personal account (between 250-300 words) of your own language learning experience addressing motivation, self-esteem, learning styles, learner strategies, interlanguage development stages; how much of your English knowledge has been learnt and how much acquired.

Term II - Write a reflective account (approx. 250-300 words) of your microteaching covering the following points: the major challenges and the experience gained; vocabulary/grammar activities tried out and the feedback received; (un)favourable classroom conditions; differences between your own learning experience and the teaching attitudes adopted in the course of studying methodology [4, p. 3, 12].

Table 1. Assessment criteria

\begin{tabular}{|l|c|}
\hline \multicolumn{1}{|c|}{ Criteria } & Weighting \\
\hline $\begin{array}{l}\text { Task fulfilment (number of words, specified points } \\
\text { covered) }\end{array}$ & $5 \%$ \\
\hline $\begin{array}{l}\text { Text composition (introduction, main body, con- } \\
\text { clusion) }\end{array}$ & $5 \%$ \\
\hline Coherence, cohesion, and accuracy of writing & $5 \%$ \\
\hline Evidence of relevant reflection & $5 \%$ \\
\hline Total & $\mathbf{2 0 \%}$ \\
\hline
\end{tabular}

Table 2. The results of the pre- and post-training assessment

\begin{tabular}{|c|c|c|c|c|c|c|c|c|c|c|c|c|}
\hline & $\begin{array}{l}\frac{1}{E} \\
\Xi \\
\frac{4}{E} \\
E \\
E\end{array}$ & 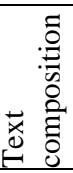 & 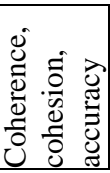 & 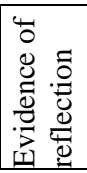 & $\stackrel{\overparen{\Xi}}{\stackrel{\Xi}{0}}$ & 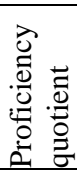 & 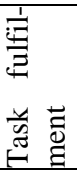 & 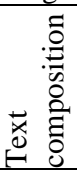 & 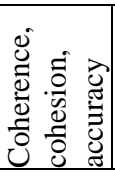 & 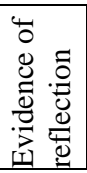 & 胥 & 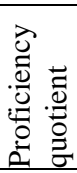 \\
\hline & \multicolumn{5}{|c|}{ Pre-training } & \multicolumn{7}{|c|}{ Post-training } \\
\hline Student 1 & $4 \%$ & $4 \%$ & $4 \%$ & $4 \%$ & $16 \%$ & 0,8 & $5 \%$ & $5 \%$ & $4 \%$ & $4 \%$ & $18 \%$ & 0,9 \\
\hline Student 2 & $3 \%$ & $3 \%$ & $3 \%$ & $2 \%$ & $11 \%$ & $\mathbf{0 , 5 5}$ & $4 \%$ & $4 \%$ & $4 \%$ & $3 \%$ & $15 \%$ & 0,75 \\
\hline Student 3 & $4 \%$ & $3 \%$ & $3 \%$ & $2 \%$ & $12 \%$ & 0,6 & $5 \%$ & $5 \%$ & $4 \%$ & $3 \%$ & $17 \%$ & 0,85 \\
\hline Student 4 & $1 \%$ & $1 \%$ & $2 \%$ & $0 \%$ & $4 \%$ & $\mathbf{0 , 2}$ & $3 \%$ & $3 \%$ & $3 \%$ & $3 \%$ & $12 \%$ & 0,6 \\
\hline Student 5 & $1 \%$ & $1 \%$ & $1 \%$ & $0 \%$ & $3 \%$ & $\mathbf{0 , 1 5}$ & $3 \%$ & $2 \%$ & $2 \%$ & $2 \%$ & $9 \%$ & 0,45 \\
\hline Student 6 & $3 \%$ & $3 \%$ & $2 \%$ & $2 \%$ & $10 \%$ & 0,5 & $4 \%$ & $4 \%$ & $4 \%$ & $3 \%$ & $15 \%$ & 0,75 \\
\hline Student 7 & $5 \%$ & $3 \%$ & $3 \%$ & $4 \%$ & $15 \%$ & 0,75 & $5 \%$ & $3 \%$ & $4 \%$ & $4 \%$ & $16 \%$ & 0,8 \\
\hline Student 8 & $4 \%$ & $3 \%$ & $2 \%$ & $2 \%$ & $11 \%$ & $\mathbf{0 , 5 5}$ & $4 \%$ & $3 \%$ & $3 \%$ & $4 \%$ & $14 \%$ & 0,7 \\
\hline Student 9 & $1 \%$ & $1 \%$ & $2 \%$ & $1 \%$ & $5 \%$ & 0,25 & $3 \%$ & $2 \%$ & $2 \%$ & $2 \%$ & $9 \%$ & 0,45 \\
\hline Student 10 & $4 \%$ & $3 \%$ & $4 \%$ & $3 \%$ & $14 \%$ & 0,7 & $4 \%$ & $4 \%$ & $4 \%$ & $4 \%$ & $16 \%$ & 0,8 \\
\hline Student 11 & $3 \%$ & $2 \%$ & $2 \%$ & $2 \%$ & $9 \%$ & 0,45 & $4 \%$ & $3 \%$ & $3 \%$ & $4 \%$ & $14 \%$ & 0,7 \\
\hline Student 12 & $3 \%$ & $2 \%$ & $3 \%$ & $2 \%$ & $10 \%$ & 0,5 & $4 \%$ & $3 \%$ & $3 \%$ & $4 \%$ & $14 \%$ & 0,7 \\
\hline Student 13 & $4 \%$ & $3 \%$ & $3 \%$ & $3 \%$ & $13 \%$ & 0,65 & $5 \%$ & $5 \%$ & $4 \%$ & $4 \%$ & $18 \%$ & 0,9 \\
\hline Student 14 & $3 \%$ & $1 \%$ & $2 \%$ & $3 \%$ & $9 \%$ & 0,45 & $4 \%$ & $3 \%$ & $3 \%$ & $4 \%$ & $14 \%$ & 0,7 \\
\hline Student 15 & $1 \%$ & $2 \%$ & $2 \%$ & $2 \%$ & $7 \%$ & $\mathbf{0 , 3 5}$ & $4 \%$ & $3 \%$ & $3 \%$ & $4 \%$ & $14 \%$ & 0,7 \\
\hline Student 16 & $3 \%$ & $2 \%$ & $2 \%$ & $3 \%$ & $10 \%$ & 0,5 & $5 \%$ & $5 \%$ & $4 \%$ & $4 \%$ & $18 \%$ & 0,9 \\
\hline Student 17 & $2 \%$ & $1 \%$ & $1 \%$ & $2 \%$ & $6 \%$ & $\mathbf{0 , 3}$ & $4 \%$ & $3 \%$ & $3 \%$ & $3 \%$ & $13 \%$ & 0,65 \\
\hline Student 18 & $3 \%$ & $2 \%$ & $2 \%$ & $1 \%$ & $8 \%$ & 0,4 & $3 \%$ & $3 \%$ & $3 \%$ & $3 \%$ & $12 \%$ & 0,6 \\
\hline Student 19 & $3 \%$ & $2 \%$ & $2 \%$ & $1 \%$ & $8 \%$ & 0,4 & $5 \%$ & $4 \%$ & $3 \%$ & $4 \%$ & $16 \%$ & 0,8 \\
\hline Student 20 & $2 \%$ & $2 \%$ & $2 \%$ & $0 \%$ & $6 \%$ & $\mathbf{0 , 3}$ & $2 \%$ & $3 \%$ & $2 \%$ & $2 \%$ & $9 \%$ & 0,45 \\
\hline Student 21 & $3 \%$ & $3 \%$ & $3 \%$ & $3 \%$ & $12 \%$ & 0,6 & $3 \%$ & $4 \%$ & $3 \%$ & $4 \%$ & $14 \%$ & 0,7 \\
\hline Student 22 & $2 \%$ & $2 \%$ & $2 \%$ & $1 \%$ & $7 \%$ & $\mathbf{0 , 3 5}$ & $4 \%$ & $3 \%$ & $3 \%$ & $4 \%$ & $14 \%$ & 0,7 \\
\hline Student 23 & $3 \%$ & $2 \%$ & $2 \%$ & $2 \%$ & $9 \%$ & 0,45 & $4 \%$ & $3 \%$ & $3 \%$ & $4 \%$ & $14 \%$ & 0,7 \\
\hline Student 24 & $1 \%$ & $2 \%$ & $2 \%$ & $0 \%$ & $5 \%$ & 0,25 & $3 \%$ & $3 \%$ & $3 \%$ & $3 \%$ & $12 \%$ & 0,6 \\
\hline
\end{tabular}


As our research was conducted within the abovementioned Methodology project and the students' reflective essays were part of the end-of-the-module assessment, we had to conform to the assessment specifications drawn up for the project. Hence the total for an essay was $20 \%$. Still, in view of our study being oriented towards writing, the criteria were modified to measure both reflection and writing skills that were the object of the training.

The pre- and post-training results are presented in Table 2, which also shows the participants' proficiency quotient at the time of performing the tasks, calculated with the help of V. P. Bespal'ko's formula $K=A / N$, where $\mathrm{A}$ - the number of points scored by students, $\mathrm{N}-$ the maximum possible number of points [2, p. 58,68]. To make it more convenient to compare the results, we highlighted the quotient figures that either equal or exceed the proficiency quotient which is considered satisfactory by V. P. Bespal'ko - 0,7 [2, p. 59].

By our calculations, over the course of the training, the average proficiency quotient rose from 0,458 to 0,702 , with 17 out of 24 students having either reached or exceeded the above-mentioned satisfactory level, which constitutes $70,8 \%$ of the group. For comparison, the number of students who initially performed at a satisfactory level was 3 out of 24 , which amounts to $12,5 \%$. All this allows us to state that the aim of our case study was accomplished in that we managed to find effective ways of teaching reflective writing.

To obtain a more accurate picture of the students' progress, we compared the pre- and post-training results by each of the criteria applied. The most significant average growth was achieved for Reflection $(1,58 \%)$, whereas the lowest - for Coherence/Cohesion/Accuracy (0,88\%). A possible explanation for this discrepancy could be the following: in some cases making students aware of what reflection is and equipping them with the basic techniques (e.g. asking questions) was sufficient to get them motivated and to trigger the corresponding thought processes, while achieving cohesion and coherence may seem to students less psychologically rewarding but very challenging and time-consuming, hence such slow progress.
As for the other two criteria, the average growth is $1,17 \%$ for Task fulfilment and 1,25\% for Text composition.

Although the general tendency is undoubtedly positive, a number of students did not demonstrate any perceivable progress: by the Task fulfilment criterion -6 students, Text composition - 2 students, Coherence/Cohesion/Accuracy - 6 students, Reflection - 2 students. It should be mentioned that in one case (Student 7) the lack of progress in terms of Task fulfilment is accounted for by the fact that the pre-training mark was the highest possible. Among the students that did make progress there are those (altogether 6) that still failed to get at least $3 \%$ out of the maximum 5\%. Even though there are apparent reasons for little or no improvement, such as irregular attendance or lack of motivation, still, considering the overall positive trend, we can presume that with more time and practice, the results will be more satisfying.

Conclusions. EFL teacher professional competence depends largely on the ability of the teacher to reflect both in and on action, i.e. to perceive themselves as professionals by analysing their methodological decisions, techniques, thoughts etc. It therefore follows that developing reflective skills should be part of English teacher training. In the case study presented in this article teaching reflection was combined with practising writing skills to encourage students to better organize their thoughts and give them more time for reflection.

As a result of the training provided for 24 students of H. S. Skovoroda Kharkiv National Pedagogical University, their average proficiency quotient reached the minimum satisfactory level 0,7 on the Bespal'ko scale, which signifies a moderately favourable outcome. It is obvious, however, that the students need to go beyond the minimum level and aim to master the skills of producing essays that fully satisfy the above-specified criteria. This objective can be achieved if students are encouraged to exercise reflective skills on a regular basis as part of the course of speaking and writing practice and some other courses on the curriculum, which could be the subject of further studies in the field of teaching reflective writing.

\section{REFERENCES}

1. Azimov, E. G. \& Shhukin A. N. (2009). New dictionary of methodological terms and concepts (Theory and practice of teaching languages). Moscow: IKAR Publ.

2. Bespal'ko, V. P. (1989). Components of pedagogical technology. Moscow: Pedagogika.

3. Bolton, G. (2014). Reflective practice: writing and professional development. London: SAGE Publications Ltd.

4. Core curriculum. English language teaching methodology. Bachelor's level. (2016). Retrieved October 5, 2017, from

http://docs.wixstatic.com/ugd/15b470_99a179aa92184262a6 70e3f8a7c2c153.pdf

5. New generation school teacher. (2016). Retrieved October 12, 2017, from http://ngschoolteacher.wixsite.com/ngscht

6. Troyka, L. Q. (1993). Simon \& Schuster Handbook for writers. Englewood Cliffs, New Jersey: Prentice Hall.

7. Wyrick, J. (2016). Steps to writing well. Boston, MA: Cengage Learning.

\section{Обучение будущих учителей английского языка рефлексивному письму}

\section{Н. Н. Одегова}

Аннотация. Рассмотрено проблему формирования умений рефлексивного письма у будущих учителей английского языка. Представлено описание тематического исследования, проведенного в Харьковском национальном педагогическом университете имени Г. С. Сковороды в 2016/17 учебном году с участием 24 студентов второго курса факультета иностранной филологии. Предложены примеры заданий, направленных на развитие умений рефлексии и написания эссе. Подтверждена эффективность обучения - средний коэффициент усвоения достиг минимального удовлетворительного уровня по В. П. Беспалько - 0,7.

Ключевые слова: умения рефлексивного письма, будущие учителя английского языка, тематическое исследование, обучение, коэффициент усвоения. 